\title{
INCREASING YIELD OF OIL FLAX BY IMPROVING TECHNOLOGICAL PROCESS OF SOWING SEEDS TOGETHER WITH HYDROGEL GRANULES
}

\author{
Mariya Nosevich \\ Saint-Petersburg State Agrarian University, Russia \\ mnosevich@yandex.ru
}

\begin{abstract}
To reduce the negative impact of arid conditions on oil flax development, moisture-retaining gels are widely used, which are placed into the soil in the form of granules before or during sowing. However, the introduction of hydrogel granules through grass seed or granular applicators with traditional flax sowing machines does not have a particular effect due to the absence of moisture concentration zones at the site where granules are placed. To increase the yield of oil flax, it is proposed to improve the technological process of sowing this crop simultaneously with the introduction of hydrogel granules. A positive effect is achieved due to the formation of local areas of compaction by a special packer roller during sowing, where seeds are sown and hydrogel granules are added. Covering the seeds and granules with a mulching layer of loose soil creates the effect of thermal insulation. At the boundary of the compacted layer, in which a profiled roller creates a network of capillary channels, and a layer of soil mulch saturated with air pores, a condensation zone of soil moisture is formed. Soil water migrates through capillaries under the influence of the phenomenon of thermoelectrokinesis. At night, soil moisture rises to the boundary of the compacted layer by capillaries and is retained by hydrogel. In the daytime, the moisture accumulated by the hydrogel is consumed by the root system of flax, ensuring plant resistance to adverse conditions with prolonged absence of rainfall. Taking into account the peculiarities of thewatermigrationin the soil capillaries, it was proposed to improve the coulter of a flax seeder for sowing flax seeds simultaneously with hydrogel granules. Improvement of the sowing process of oil flax seed with the introduction of hydrogel granules was made based on taking into account the movement of soil moisture under the influence of a temperature gradient. Due to the combination of the coulter with roller for compaction bottom of furrow, the application of the granular preparations in same row with oil flax seed and further covering by mulched soil reached positive effect.
\end{abstract}

Keywords: oil flax, hydrogel, packer roller, flax drill.

\section{Introduction}

Soil moisture is one of the limiting factors of crop yields [1]. A feature of oil flax is an underdeveloped root system [2], which develops mainly in the upper layers of the soil horizon. Therefore, one of the directions for improving the technology of cultivation of oil flax is to create conditions for sufficient moisture supply of plants with a long absence of rainfall.

During growing of oil flax the level of moisture supply of plants during the growing season has a significant effect. Weather conditions in the North-West region of Russia are characterized by instability of natural phenomena. Therefore, with a long period of lack of rainfall during the growing season of oil flax, there is a decrease in the yield and seed quality. To reduce the negative impact of arid conditions on plant development, moisture-retaining gels are widely used, which are placed into the soil in the form of granules before or during sowing. A feature of moisture-retaining gels is the ability to absorb free moisture with a lower level of osmosis compared to the root system of plants. Therefore, hydrogels do not compete for water with the root system and freely give it to plants during periods of insufficient soil moistening. However, the introduction of hydrogel granules through the grass seed boxes or granular applicators with traditional flax sowing machines does not have a particular effect due to the absence of moisture concentration zones at the site where granules are placed.

Analysis of the wetness of the root spreading zone showed that the movement of moisture inside the soil occurs when there is a temperature difference between the sections of soil capillaries [3]. In this case, soil water moves inside the capillary channels into the zone with a lower temperature. The intensity of water movement depends on the value of the temperature gradient; therefore, in the spring and summer periods, when the upper soil horizon is heated, a steady outflow of water to the underlying layers of the soil horizon is observed. Therefore, plants with an underdeveloped root system experience stress during the hot period with a long absence of precipitation due to the impossibility of root penetration to a considerable depth.

In the summer period, in addition to the seasonal migration of soil moisture directed to the underlying layers, with a difference in day and night temperatures, there is a reverse movement of 
water at night, when the soil surface is cooled. Therefore, improving the technology of growing crops with an underdeveloped root system is aimed at the accumulation of moisture in the upper layer during its daily migration and a decrease in the intensity of outflow of water to the lower layers of the soil horizon with increasing of the average daily temperature.

Recently, to ensure a favorable regime of soil wetness, granular polymer water-retaining compounds are used, which are able to absorb free moisture with a low level of osmosis, without creating competition for the plant root system. Such polymers called hydrogels are cross-linked materials absorbing large quantities of water without dissolving that absorb substantial amounts of aqueous solutions made from petroleum product [4]. When saturated with water, such polymers stretch and turn into gel capable of retaining moisture the volume of which is 250-300 times the mass of granules. The root system of plants easily penetrates into such gel and assimilates the aqueous solution inside it. This provides plants with moisture that has accumulated inside the hydrogel, regardless of the level of soil moisture. Hydrogel retains its effect in the soil for 3-4 years, gradually decomposing into elementary organic elements; therefore it poses no danger to the environment. Hydrogel granules can be scattered across the soil and embedded in the topsoil, and in order to sufficiently increase the water-holding ability of the root layer, must be applied at a rate of at least $150-200 \mathrm{~kg} \cdot \mathrm{ha}^{-1}[5]$. This application rate makes it inappropriate to use such a method of introducing hydrogel granules during growing of oil flax for economic indicators.

To increase the yield of oil flax, it is proposed to improve the technological process of sowing this crop simultaneously with the introduction of hydrogel granules. A positive effect is achieved due to the formation of local areas of compaction by a special packer roller during sowing, where seeds are sown and hydrogel granules are added. Covering the seeds and granules with a mulching layer of loose soil creates the effect of thermal insulation. At the boundary of the compacted layer, in which a profiled roller creates a network of capillary channels, and a layer of soil mulch saturated with air pores, a condensation zone of soil moisture is formed. Soil water migrates through capillaries under the influence of the phenomenon of thermoelectrokinesis. At night, soil moisture rises to the boundary of the compacted layer by capillaries and is retained by hydrogel. In the daytime, the moisture accumulated by the hydrogel is consumed by the root system of flax, ensuring plant resistance to adverse conditions with prolonged absence of rainfall.

Improvement of the sowing process for simultaneous introduction of hydrogel granules was made based on taking into account the movement of soil moisture under the influence of a temperature gradient. Due to the selection and rational combination of rolling working bodies, the coulter group of the flax seeder, the system for application granular preparations in a row with seed and mulching working bodies reached positive effect.

Long-term experimental studies have shown the high efficiency of such sowing technology, which allowed increasing the yield of oil flax seeds by 14-20\%, depending on the level of precipitation.

\section{Materials and methods}

In order to reduce the cost of acquiring hydrogel granules and increase the efficiency of its use with a tenfold decrease in the application rate, it was proposed to improve the flax seeder. The seeder was improved by equipping it with a hydrogel granule introduction system, the distribution system of which delivered a preparation to each opener of the seeder (Fig. 1) by analogy with a potato planter equipped with a hydrogel granulation system [6]. The granules of the hydrogel were placed directly in the oil flax seed placement zone. To ensure the greatest effect of moisture accumulation by hydrogel granules, it was proposed to improve the drill coulter group by equipping it with a profiled roller designed to compact the seed bed (Fig. 2). Behind each coulter 1, a profiled roller 2 is installed on the spring-loaded suspension, which compacts the bottom of the furrow.

During soil consolidation by the roller it outer profile forms a dense furrow bottom, into which flax seeds and hydrogel granules are delivered by the seed tube 3. Covering by soil of seeds and granules is carried outby rear spring tines 4 , which are pushing the loosed soil to the center of the row and leveling the surface of the field. 


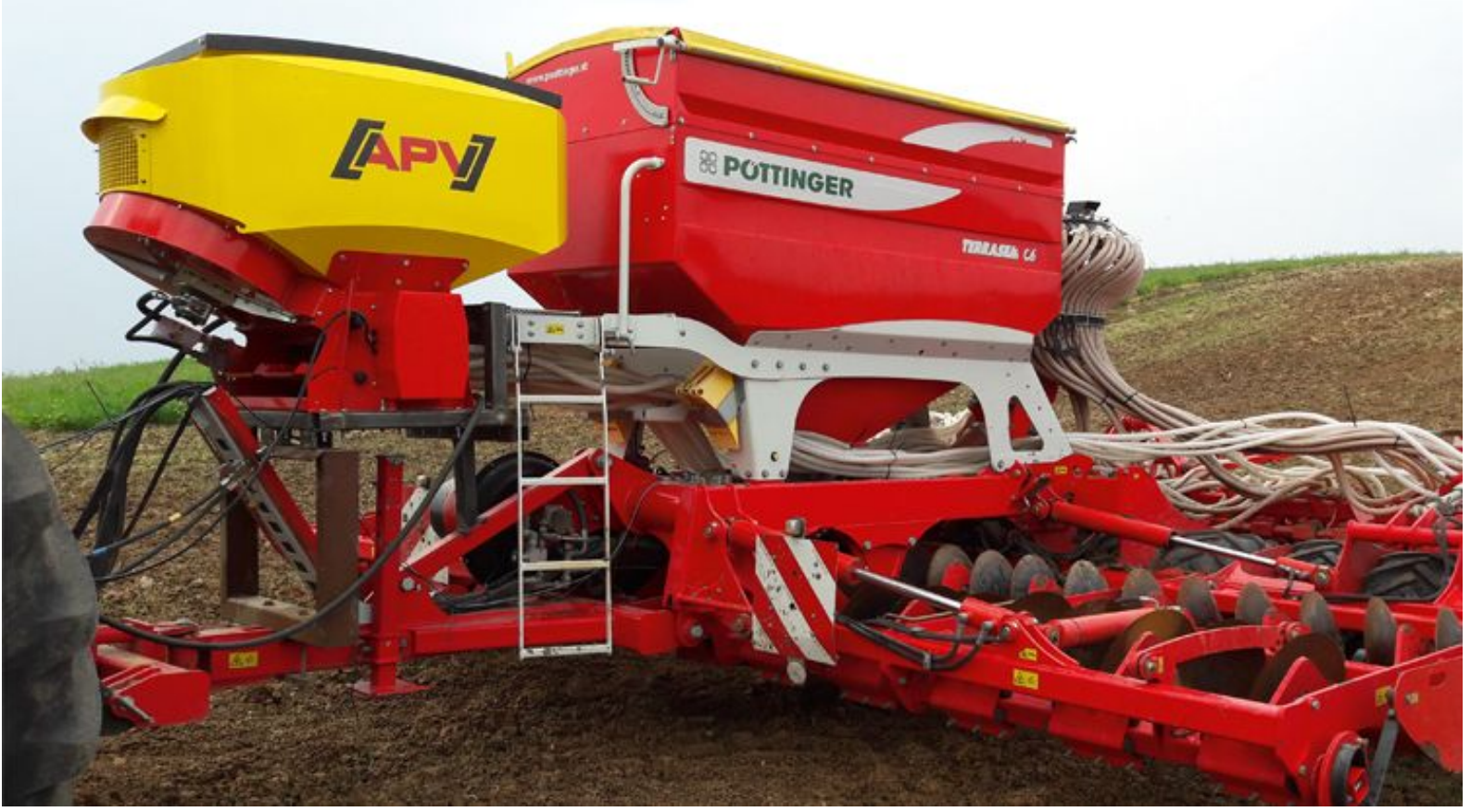

Fig. 1. Seeder for hydrogel granules on the grain drill

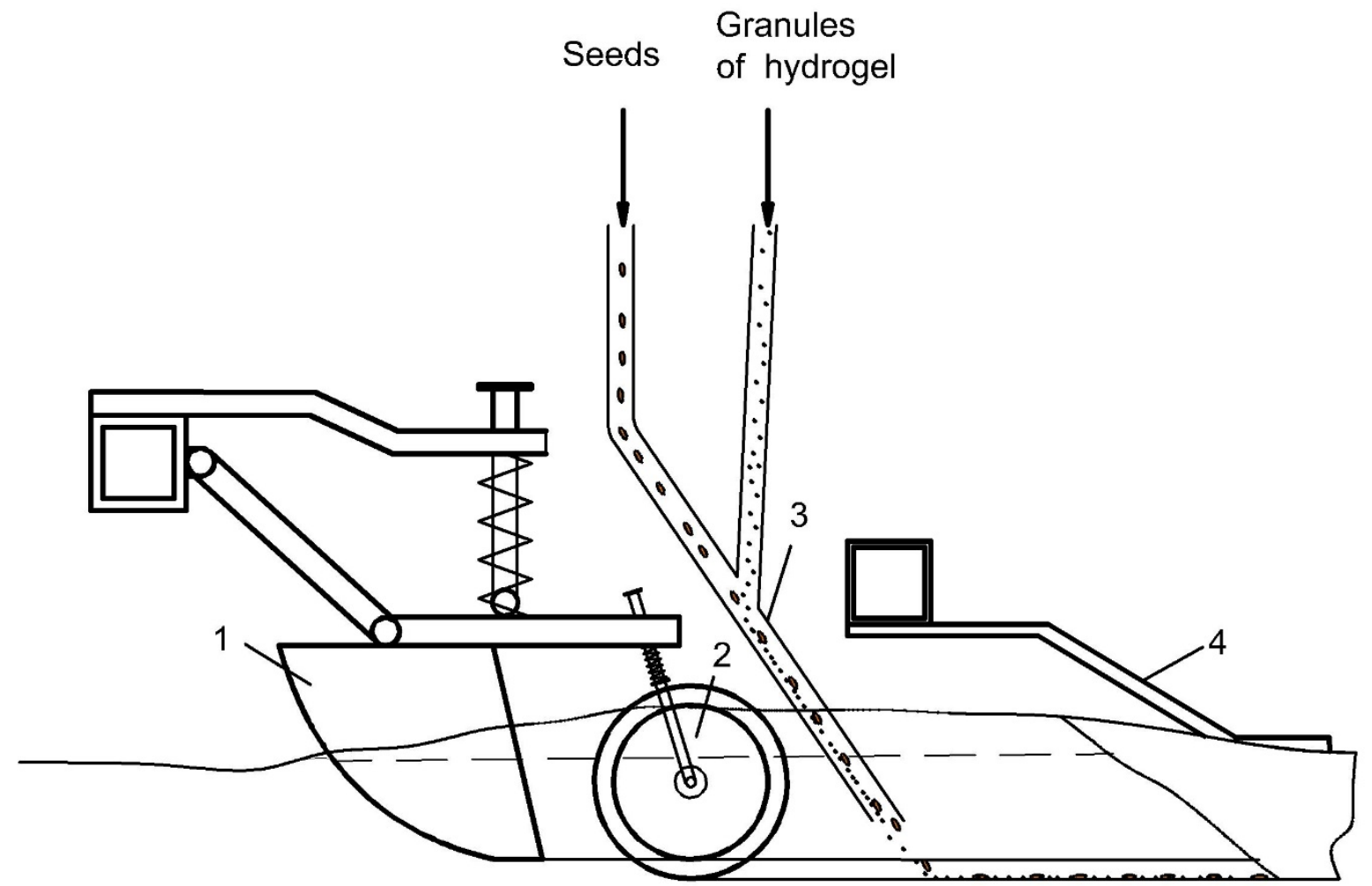

Fig. 2. Scheme of the coulter system for sowing flax seeds and hydrogel granules

After the passage of such an improved coulter along the perimeter of the bottom of the profiled groove, a compacted zone is formed, saturated with a network of capillary channels (Fig. 3), along which moisture moves under the influence of a temperature difference between the upper and lower layers of the soil horizon [7]. The presence of a significant amount of air in the loose soil layer covering the furrow excludes heating of its bottom due to good thermal insulation of such soil structure. Thermal insulation in the upper soil layer significantly reduces the rate of moisture 
movement to the lower soil layers due to a slight temperature difference in the soil layers below the sowing depth. The same circumstance ensures the rapid rise of the soil solution to the walls of the furrow at night, when the soil temperature at a depth of $10-15 \mathrm{~cm}$ becomes higher than the temperature of the upper soil layer. When the soil solution reaches the border of dense and loose soil at the bottom of the furrow, moisture condenses and then is absorbed by hydrogel. Hydrogel retains moisture and eliminates its reverse migration to the underlying layers in the daytime when the soil surface is heating $[8 ; 9]$. The root system of plants penetrates the hydrogel granules and penetrates through the capillary channels into the underlying layers of the soil horizon, which contain reserves of moisture and nutrients. The presence of a water buffer from the hydrogel in the zone of development of the root system eliminates plant stress caused by the lack of precipitation and high temperatures $[10 ; 11]$, because replenishment of moisture inside the granules occurs at night.

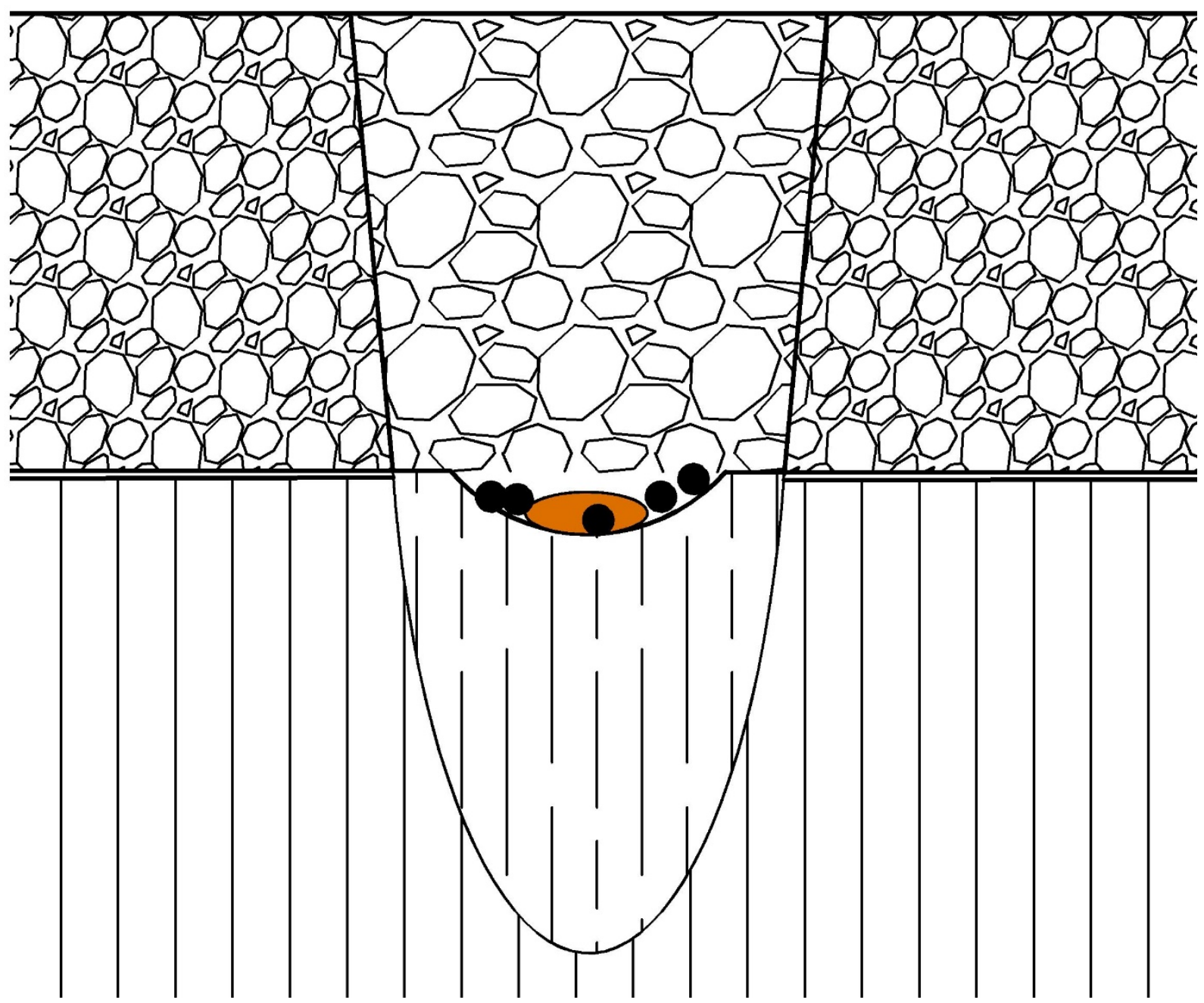

Fig. 3. Layout of flax seeds and hydrogel granules after sowing with an improved opener

Experimental studies of the effect of joint sowing of oil flax seeds and hydrogel granules on yield and product quality were carried out in the experimental fields of the St. Petersburg State Agrarian University. Sowing was completed on May 9, when the soil reached the phase of physical ripeness. The seeding rate of flax seeds in the control and experimental plots was $50 \mathrm{~kg} \cdot \mathrm{ha}^{-1}$, the rate of application of the hydrogel was $18 \mathrm{~kg} \cdot \mathrm{ha}^{-1}$. The sowing was performed with a special selection seeder SS-11 "Alfa" equipped with advanced openers. The hydrogel granules were sown by the APV PS 200 M1 pneumatic seeder. The seeding rate of seeds and granules of hydrogel was adjusted by tuning the rotation speed of the seed coils. Each experimental plot $50 \mathrm{~m}^{2}$ was sown in 4-fold repetition in accordance with the generally accepted methodology [12]. Morphological parameters of plants were measured on area $1 \mathrm{~m} 2$ in the each plot at the end of the growing season before harvesting. Harvesting was done on 5 September by a special selection harvester SampoRosenlev 2010. 


\section{Results and discussion}

During the experimental studies, the quantitative and qualitative indicators of plants sown together with hydrogel were evaluated in comparison with the control sowed without hydrogel. The assessment was carried out according to two indicators: plant morphology and yield. Morphological assessment was carried out according to the main indicators characterizing the general structure of oil flax plants and the yield was the final result of the use of hydrogel in comparison with the control variant.

The results of the morphological evaluation of plants are presented in Table 1.

Morphological parameters of oil flax plants in studies of hydrogel

Table 1

\begin{tabular}{|c|c|c|c|c|c|c|c|c|c|c|}
\hline \multirow[b]{2}{*}{$\begin{array}{l}\text { Variant of } \\
\text { experience }\end{array}$} & \multicolumn{3}{|c|}{ Length, cm } & \multicolumn{3}{|c|}{ Stem diameter, mm } & \multirow{2}{*}{$\begin{array}{c}\text { Stem } \\
\text { refine- } \\
\text { ment } \\
\left(D_{1}-D_{2}\right), \\
\text { mm }\end{array}$} & \multicolumn{3}{|c|}{ Quantity, pcs. } \\
\hline & $\begin{array}{l}\text { Whole } \\
\text { stalk }\end{array}$ & $\begin{array}{l}\text { Technic } \\
\text { alpart }\end{array}$ & $\begin{array}{l}\text { Inflore } \\
\text { scence }\end{array}$ & $\begin{array}{c}D_{1} \\
\text { bottom }\end{array}$ & $\begin{array}{c}D_{2} \\
\text { middle }\end{array}$ & $\begin{array}{l}D_{3} \\
\text { top }\end{array}$ & & $\begin{array}{l}\text { Stems/ } \\
\text { plant }\end{array}$ & $\begin{array}{c}\text { Capsule / } \\
\text { plant }\end{array}$ & $\begin{array}{c}\text { Seeds/ } \\
\text { plant }\end{array}$ \\
\hline $\begin{array}{c}\text { Sowing } \\
\text { with } \\
\text { hydrogel }\end{array}$ & 62.5 & 45.5 & 17.0 & 1.7 & 1.6 & 1.3 & 0.4 & 2.4 & 32.4 & 275.6 \\
\hline Control & 62.2 & 43.8 & 18.4 & 1.6 & 1.5 & 1.4 & 0.2 & 2.8 & 25.3 & 219.1 \\
\hline $\mathrm{LSD}_{05}$ & 2.6 & 4.3 & 0.8 & - & - & - & - & 0.3 & 1.1 & 7.7 \\
\hline
\end{tabular}

An analysis of Table 1 showed that when using hydrogel due to better water supply to the plants, a longer technical part of plants with more compact inflorescences is noted, the average value of the diameter of the stems at their base is increased compared to the control, and on the upper part the value of this indicator becomes less. This structure of the stalk provides a higher resistance of plants to lodging under the influence of adverse weather conditions. Stabilization of the plant's moisture supply during the introduction of the hydrogel leads to the formation of a smaller number of stems per plant, however, each stalk has greater productivity compared to the control variant, because they show an increased number of seed capsules, and, accordingly, the number of seeds. Thus, the morphological assessment of plants using hydrogel showed that with an equal height of the stem and fewer branches on each plant, an increase in the number of seed capsules is noted. This fact is evidenced by the presented indicators of the Least Significant Difference (LSD).

The results of evaluating the yield of oil flax when using hydrogel, in comparison with the control variant are shown in Table 2.

Table 2

Oil flax seed yield with hydrogelapplication

\begin{tabular}{|c|c|c|c|c|c|c|}
\hline Variantofex & Q-typlant, & \multicolumn{3}{|c|}{ Weight, g } & \multicolumn{2}{c|}{${\text { Productivity, t } \cdot \mathbf{h a}^{-1}}^{-1}$} \\
\cline { 3 - 7 } perience & pcs. $\mathbf{m}^{-2}$ & Capsule/plant & Seeds/plant & $\mathbf{1 0 0 0}$ seeds & Biological & Actual \\
\hline $\begin{array}{c}\text { Sowing with } \\
\text { hydrogel }\end{array}$ & 355 & 1.87 & 1.47 & 5.39 & 5.23 & 2.39 \\
\hline Control & 369 & 1.55 & 1.22 & 5.56 & 4.51 & 1.31 \\
\hline LSD $_{05}$ & 5.7 & 0.23 & 0.18 & 0.09 & 0.34 & 0.20 \\
\hline
\end{tabular}

Analysis of the data presented in Table 2 showed that the use of hydrogel provides an increase in the yield of oil flax seeds, despite a smaller number of plants in the control plot, a decrease in the number of seeds in the capsules and the weight of 1000 seeds. The increase in the yield is ensured by the formation of a larger number of seed capsules per plant. A significant difference in the actual yield after mechanized harvesting of oil flax indicates that when hydrogel is applied and a stable water supply is formed, a plant structure that is more resistant to lodging is formed, which significantly reduces seed loss under adverse weather conditions. The presented indicators of LSD show a reliable increasing yield, when hydrogel is applied simultaneously with sowing oil flax.

\section{Conclusions}

As a result of scientific studies of the moisture transfer inside the soil capillaries under the influence of natural factors, it was proposed to use local introduction of hydrogel granules into the 
seed zone during the sowing to increase the yield of oil flax seeds. The presence of hydrogel granules saturated with water near the root system creates moisture reserves that are available to plants in the absence of precipitation. Many researchers have found that the presence of moisture in the upper layer, where the seeds and granules of hydrogel are placed, significantly reduces plant stress on hot summer days. Therefore, it is necessary to create conditions for the regular supply of soil solution to the zone of placement of hydrogel granules.

To ensure regular feeding of hydrogel granules with moisture and increasing the efficiency of their action, the regularity of movement of subsoil moisture under the influence of a temperature difference at night was used. The movement of moisture in the area of placement of the hydrogel and seed material at night is intensified by improving the design of the seed drill coulter by installing a profiled packer roller in it, which forms a seal on the bottom of the furrow, where flax seeds and hydrogel granules are placed. After the passage of such a coulter, the soil structure has a dense furrow bottom formed by a profiled roller with a large number of capillary channels, and the seed is covered with a loose layer of soil saturated with air pores, which has good thermal insulation properties. When the surface of the soil is cooled at night, moisture moves up through the capillaries from the lower layers of the soil horizon and, after condensation at the border of the dense and loose layers, is absorbed by hydrogel granules, after which it becomes available to the root system of plants in the daytime, when the bulk of the moisture migrates to the underlying layers with increasing outside temperature.

Field studies and analysis of the results of the assessment of the morphological structure of plants showed that when hydrogel is introduced during sowing of oilseed flax, the internal structure of plants is more resistant to lodging. With stable moisture supply to plants, a larger number of seed capsules are formed on them, which leads to increased yields. The increase in biological productivity amounted to $0.72 \mathrm{t} \cdot \mathrm{ha}^{-1}$ compared with the control variant, the difference in actual productivity after mechanized harvesting was $1.08 \mathrm{t} \cdot \mathrm{ha}^{-1}$ due to the stable structure of the stalk. Statisticsof the Least Significant Difference showed reliable increasing of yields with hydrogel application using an advanced drill with improved coulter.

\section{References}

[1] Lupova E., Vysotskaya E., Vinogradov D. Improvement of elements of oil flax cultivation technology on gray forest soil. IOP Conference Series: Earth and Environmental Science. 422. 012081, 2020. DOI: 10.1088/1755-1315/422/1/012081.

[2] Vinogradov D. V., Lupova E. I., Byshov N. V., Kruchkov M. M. and Fadkin G. N. Production of Oil Flax Seed in Non-Black Earth Zone of Russia International Journal of Advanced Biotechnology and Research (IJABR) 10 (2), 2019, pp. 406-416.

[3] Kalinin A., Teplinsky I., Ustroev. A. Substantiation of tillage methods aimed at rational usage of water resources. Engineering for Rural Development. 17th International Scientific Conference. 2018, pp. 392-399.

[4] Neethu T.M., Dubey P., Kaswala A. Prospects and Applications of Hydrogel Technology in Agriculture. International Journal of Current Microbiology and Applied Sciences. 7, 2018, pp. 3155-3162. DOI: 10.20546/ijcmas.2018.705.369.

[5] Montesanoa F.F., Parentea A., Santamariab P., Sanninoc A., Serioa F. Biodegradable superabsorbent hydrogel increases water retention properties of growing media and plant growth. Agriculture and Agricultural Science Procedia 4, 2015, pp. 451-458.

[6] Калинин А.Б., Шпиганович П.М. Повышение эффективности способов регулирования водного режима почвы при возделывании картофеля.Kalinin A.B., Shpiganovich P.M. Improving efficiency of ways of regulating water soil regime in production of potato. Agroindustrial complex: state, development trends and prospects, personnel training: A collection of scientific papers of the National Scientific and Practical Conference "Agro-industrial complex of the Leningrad Region: state, development trends and prospects, personnel training" as part of the Business Program of the Agricultural Technology Exhibition "All-Russian Field Day - 2019" ( July 10-12, 2019)/SPbGAU. - SPb. 2019/ pp. 93-96 (In Russian). 
[7] Дыдышко П.И. Земляное полотно железнодорожного пути. Справочник. Dydyshko PI. The road bed oft he railway. Handbook: scientific works of JSC VNIIZhT. Moscow, Intext, 2014, 416 p. (InRussian).

[8] Morteza B., Naimeh M., Mehdi M. An introduction to hydrogel and some recent application. DOI: $10.5772 / 64301$

[9] Neethu T.M., Dubey P.K., Kaswala A.R. Prospects and applications of hydrogel technology in agriculture. Int. J. Curr. Microbiol. App. Sci. 7(05), 2018, pp. 3155-3162.

DOI: 10.20546/ijcmas.2018.705.369

[10] Kalhapure A, Kumar R, Singh V.P., Pandey D.S. Hydrogels: a boon for increasing agricultural productivity in water-stressed environment. Current Science 111(11) 2016, pp. 1773-1779.

[11] Narjary B., Aggarwal P., Singh A., Chakraborty D., Singh R. Water availability in different soils in relation to hydrogel application. Geoderma 187. 2012, pp. 94-101.

[12] Доспехов Б.А. Методика полевого опыта. Dospekhov B. A. Methods of field experiment (with the basics of statistical processing of research results): a textbook for students of higher agricultural educational institutions in agronomic specialties. - 5-th ed. Moscow: Agropromizdat. 1985. - 351 p. (In Russian). 